Revista Iberoamericana, Vol. LXXVIII, Núm. 241, Octubre-Diciembre 2012, 819-837

\title{
GÉNERO Y ESPACIO: LA CASA EN EL IMAGINARIO SUBALTERNO DE ESCRITORAS LATINOAMERICANAS
}

\author{
POR \\ LuCía GuERRA-CunNINGHAM \\ University of California, Irvine
}

En la vasta bibliografía acerca de la ciudad, llama la atención el énfasis otorgado a los espacios públicos en una dinámica que implica tanto el tránsito constante como la proliferación y diseminación de sus signos. No obstante las casas configuran gran parte de la ciudad, en estos estudios, ellas son el artefacto urbano estático y silencioso que no merece mayores comentarios, esa presencia a la que se alude cuando se trata de un proyecto urbanístico determinado o ese conjunto colectivo mencionado en términos de una fachada que lo une a la calle.

Puesto que desde una perspectiva geográfica y antropológica, el espacio se produce bajo factores socio-culturales insertos en un sistema genérico, el paradigma que divide la ciudad entre "lo público" y "lo privado" debe comprenderse como parte de un fundamento ideológico que refuerza las diferencias atribuidas a "lo femenino" y "lo masculino”. Como señala Jane Rendell, el predominio del espacio público asociado con una producción de carácter masculino (la ciudad) y la devaluación de lo privado ligado a la mujer y la reproducción biológica (casa, hogar) responde a la estructura patriarcal y su método falogocéntrico de concebir, organizar y analizar la realidad (Rendell 103). La división en esferas separadas remite históricamente a la ciudad griega y su bien delimitada polis que correspondía al espacio público, tanto en términos de los lugares materiales que lo configuraban como aquel ámbito de acciones guiadas hacia el quehacer político. Connotación que ha perdurado pues aún el espacio público se considera como mediador entre la sociedad y el estado en múltiples expresiones de la ciudadanía. El énfasis dado al espacio público en los estudios acerca de la ciudad resulta no sólo de una devaluación implícita con respecto al entorno asociado a la mujer en su calidad de ciudadana de segunda categoría sino también a los emisores de dichos discursos producidos, en abismante mayoría, desde una perspectiva masculina. 
INADECUACIONES DEL IMAGINARIO ANDROCÉNTRICO

La división entre hombres y mujeres bajo un régimen heterosexual plantea la casa, desde una visión androcéntrica, como un lugar de descanso y recogimiento para los hombres afanados en las tareas del trabajo y una praxis histórica teñida de conflictos y hazañas. Noción que se reitera en textos tan diversos como La perfecta casada (1583) de Fray Luis de León, Emilio (1762) de Jean-Jacques Rousseau y Sistema de política positivista (1848) de Augusto Comte. Parafraseando a Friedrich Nietzsche, se podría aseverar que en la cultura de occidente, la casa ha sido el lugar del reposo del guerrero y como tal, ha estado relegada en los márgenes de la Historia oficial y sus sucesos canónicos. Noción que permite a Hommi Bhabha referirse a lo "unhomely" (lo "no hogareño") basado en concepto freudiano de lo inquietante (umheilich) como aquella reacción de miedo e inseguridad cuando se produce la extraña y siniestra irrupción de la Historia en el espacio privado de la casa (Bhabha).

Sin embargo, como han demostrado los estudios feministas, en la casa también transcurre la Historia, pero se trata de una Historia Otra con un ritmo y contenido que ponen en entredicho los parámetros de la Historia oficial organizada a partir de los criterios de una hegemonía masculina. En la tradicional oposición entre el devenir histórico de los hombres y el devenir histórico de las mujeres, la casa resulta ser el entorno y escenario de otras instancias históricas que van desde las importantes relaciones interculturales e intercambio de saberes (fenómeno clave en el caso de la cultura latinoamericana) al desarrollo de la medicina casera, las prácticas de la sexualidad, los métodos anticonceptivos, la invención de artefactos caseros y la entrada en la casa de diferentes medios de comunicación masiva (folletines, radio, televisión).

Lejos de ser ese lugar estático y omitible en los discursos acerca de la ciudad, la casa posee una pluralidad de significados en su función de albergue para la familia, verdadera estructura nuclear de la nación. Desde el punto de vista de la injerencia del Estado, la casa, además de constituir un ámbito de la intimidad, jurídicamente corresponde a un domicilio, importante dato de identificación ciudadana y desde la esfera política, es también un recinto con ciertos derechos, obligaciones y privilegios. Más importante aún, la casa es el primer lugar de entrenamiento para los futuros ciudadanos: es allí donde los niños aprenden el control y pautas culturales del cuerpo, los primeros procesos de normalización social, un sentido de la individualidad y los guiones performativos de "lo femenino" y "lo masculino".

En contraposición a los espacios públicos de la ciudad, sinónimo de despliegue, disipación y exterioridad, la casa equivale al repliegue y la interioridad, a un abandonar el disimulo en relaciones meramente funcionales para vivir el "nosotros" de la familia y la consagüinidad en una cohesión afectiva que resulta ser la metáfora de la comunidad imaginada de la nación. Anclaje identitario que no sólo revierte a los orígenes en la

\footnotetext{
(3) Revista Iberoamericana, Vol. LXXVIII, Núm. 241, Octubre-Diciembre 2012, 819-837 ISSN 0034-9631 (Impreso) 
genealogía familiar sino también a una memoria compartida que se nutre tanto de lo oral como de los objetos que existen en la casa. En su calidad de "espacio propio", es allí también donde se relaja el sujeto a través de sus ratos de ocio, sus hábitos caseros, la decoración de su entorno hogareño y un cuerpo que se despoja de las regimentaciones públicas.

Pero aparte de estos aspectos, la casa es también el lugar de lo secreto y lo prohibido, de la violencia intrafamiliar y la imposición de la autoridad. Elementos recurrentes en folletines, radiodramas, películas y telenovelas que se han nutrido de los conflictos, rencores y abusos en una privatización de la tragedia que pone de manifiesto, a pesar de los desenlaces felices creados por la moral ingenua, las tensiones dentro de la eufemística “armonía del hogar”.

La casa, desde los albores de la cultura de occidente, es también un espacio del poder, la vigilancia y el orden jerárquico. Tradicionalmente, el pater familias en su imperio doméstico ha reiterado la supremacía de lo masculino a nivel del Dios-Padre, de los padres canónigos y los otros hombres en posiciones de poder. Él es el poseedor, como señalan los estudios sicoanalíticos, de un Orden Simbólico creado desde una perspectiva androcéntrica que ha silenciado las voces de las mujeres sin acceso, hasta fines del siglo xIx, a la educación. Es más, el patriarcado ha tenido como fundamento una espacialización en la cual la casa resulta ser el cerco territorializador impuesto a la mujer en su posición subalterna.

Y en este sentido, la casa deja de ser sencillamente uno de los lugares de la ciudad. Por el contrario, se convierte en una espiral que va de la clausura espacial a la no participación en la cultura oficial y una mutilación de la existencia. En La perfecta casada (1583) que pone en evidencia un paradigma señero en la tradición hispánica, Fray Luis de León asevera:

Porque, así como la naturaleza, como dijimos y diremos, hizo á las mujeres para que encerradas guardasen la casa, así las obliga a que cerrasen la boca; [...] por donde, así como a la mujer buena y honesta la naturaleza no la hizo para el estudio de las ciencias, ni para los negocios de dificultades, sino para un solo oficio simple y doméstico; así les limitó el entender, y por consiguiente les tasó las palabras y las razones [...] (200)

En el discurso de Fray Luis de León, la casa es ese elemento material y tangible que le sirve como trampolín para tachar la participación de la mujer en ese afuera de la Historia y la Cultura. Una de sus prescripciones señala que la mujer debe ser como una tortuga, "un animal mudo y que nunca desampara su concha” (201). Es decir, un ente enclaustrado que carece de inteligencia y no tiene derecho al uso del lenguaje pues está despojado de toda opinión válida. La casa deviene, así, en la estructura concreta que enmarca el paradigma de la subordinación de la mujer y todo el proceso de territorialización fundamentado en el binarismo genérico entre la producción económica

Revista Iberoamericana, Vol. LXXVIII, Núm. 241, Octubre-Diciembre 2012, 819-837 ISSN 0034-9631 (Impreso) 
y la reproducción biológica. Fundamento que, como demostrara Simone de Beauvoir en El segundo sexo (1949), se extiende incluso a la esfera de la alteridad existencial que ha hecho del hombre un sujeto de lo trascendente mientras la mujer es el otro subalterno que permanece en la inmanencia.

En su rol primario de madre y esposa relegada en el ámbito doméstico, la praxis de la mujer está fuera de la noción prevalente de productividad concebida como el intercambio de trabajo por remuneración económica, razón por la cual sus labores han recibido la denominación de trabajo invisible. Cercada por las paredes de la casa, su rutina diaria se desplaza por un espacio donde predomina la cercanía y la contigüidad que contrastan con la extensión desafiante de la ciudad allá afuera. Su trabajo corresponde a un Hacer que perdura de manera fugaz: las camas se vuelven a deshacer, los muebles y el piso se vuelven a ensuciar y ese guiso que requirió tanta dedicación es consumido en menos de media hora. Muy lejos de ser la musa inspiradora en el imaginario creado desde una perspectiva masculina, ella reitera la actividad de Penélope tejiendo y destejiendo la mortaja para su suegro Laertes mientras mantiene intacta la trama familiar durante la ausencia azarosa de Ulises. Además, a diferencia del tiempo cursivo de la nación en un movimiento teleológico de la Historia, en la casa, lo rutinario e intrascendente gira alrededor de un tiempo cíclico donde todo se repite.

En el imaginario androcéntrico, ha persistido la asociación que se establece entre la casa y el útero. Éste, en el campo semántico de un espacio cerrado que nutre y alimenta, facilita una relación homológica con la casa que también se piensa en términos del origen. Homología que se hace evidente en La poética del espacio donde Gastón Bachelard afirma:

En la vida del hombre, la casa anula todas las contingencias y provee incesantemente el espacio de la continuidad. Sin ella, el hombre sería un ser disperso. Lo sostiene a través de las tormentas del cielo y las tormentas de la vida [...] Es el primer mundo del ser humano. Antes de "ser lanzado al mundo”, como dicen los metafísicos rápidos, el hombre es depositado en la cuna de la casa. Y en la imaginación, la casa es una enorme cuna [...] La vida siempre empieza bien porque se inicia en el lugar cerrado, protegido y cálido del vientre de la casa. (37)

La casa como vientre materno es, para Bachelard, aquel espacio que protege de todas las contingencias de un Afuera que el hombre, en sus funciones productivas y políticas, debe enfrentar. Desde una perspectiva similar, Humberto Giannini define la casa en el contexto del viaje cotidiano que se realiza para salir a trabajar. La salida a la calle implica entrar a un territorio abierto, de enfrentamiento con lo Otro y los otros donde cualquier cosa puede ocurrir. Son las calles en una circulación incesante las que lo conducen a su lugar de trabajo donde el sujeto debe exhibir su disponibilidad para lo Otro en un tiempo externo y mediatizado. Sólo al regresar a su casa, podrá volver a ser

\footnotetext{
Revista Iberoamericana, Vol. LXXVIII, Núm. 241, Octubre-Diciembre 2012, 819-837 
para sí mismo. Lejos del trámite y la feria, el sujeto regresa a una continuidad espacial y temporal que funciona como verdadero eje y soporte de su existencia. Por esta razón, afirma Giannini, no se trata de "mi yo" planteado por filosofía subjetivista, ni de "mi ser en el mundo", según Heidegger, sino de "mi yo domiciliado” (Giannini 25).

Llama la atención que dentro de la trascendencia atribuida a la casa, persista su homología con el útero.

Cuando traspaso la puerta, el biombo o la cortina que me separa del mundo público; cuando me descalzo y me voy despojando de imposiciones y máscaras, abandonándome a la intimidad del amor, del sueño o del ensueño, entonces cumplo el acto más simple y real de un regreso a mí mismo; o más a fondo todavía: de un regressus ad uterum -es decir, a una separatibidad protegida de la dispersión de la calle -el mundo de todos y de nadie-, o de la enajenación del trabajo. (Giannini 24)

En La 'reflexión' cotidiana: Hacia una arqueología de la experiencia, Giannini omite las experiencias de la mujer en su rol de "ama de casa". Marginada de toda "reflexión" que implica una salida, un viaje al afuera y un retorno a la casa, su trabajo doméstico en el espacio que, desde una perspectiva masculina, es sinónimo de un regreso al útero y a un sí mismo, no conlleva el sentido de "aventura" implícito en aserciones de Bachelard y Giannini. No obstante las mistificaciones androcéntricas de la maternidad y el rol de la mujer como "guardiana del hogar", cabe preguntarse hasta qué punto ella tiene la experiencia de ser para sí misma en una casa llena de quehaceres que satisfacen las necesidades del resto de la familia. Es más, en la situación actual donde un alto porcentaje de mujeres se ha incorporado al campo laboral, habría también que redefinir las experiencias del "recogimiento y el descanso" dentro del contexto de la "doble jornada" en la cual participan hombres y mujeres. Es interesante, además el hecho de que Bachelard y Giannini utilicen la mítica figura del Homo Viator inserta en larga tradición épica del "hombre que viaja" enfrentando peligros y tempestades. Así, aunque ahora se trate del trabajo diario a un nivel, más o menos, pedestre, la salida y experiencia en la esfera pública, en ese sector dinámico de calles y desafíos, sigue siendo "una aventura”.

En la homología casa-útero, se inserta un tercer elemento implícito: la mujer configurando una tríada que resulta ser el asilo permanente para el hombre en sus actividades en el Mundo de Afuera. Pero habría que preguntarse si el útero significa lo mismo para el hombre y la mujer. ¿ No habrá, tal vez, otras connotaciones de la casa para quien vive la experiencia de la maternidad, el dolor del parto y las enfermedades de ese útero en cuerpo de mujer? ¿Hasta qué punto la casa sólo significa amparo, protección y alimento cuando ese espacio cerrado constriñe la existencia y exige una multitud de quehaceres?

Revista Iberoamericana, Vol. LXXVIII, Núm. 241, Octubre-Diciembre 2012, 819-837 
En el corpus de la novela latinoamericana escrita por mujeres, la casa es un espacio recurrente, un eje ficcional de diferentes significados en una resemantización que responde, en gran parte, a las diferentes ideologías feministas que se han dado en un contexto político y cultural específico. En este sentido, el término "cronotopo" (lugar en tiempo y espacio determinados) resulta insuficiente puesto que Bajtín no tomó en cuenta lo genérico como un factor que permea todo sistema de signos y lo complejiza produciendo escisiones significativas. En estas novelas, la casa funciona en un doble contexto: el del imaginario predominante a partir de una noción masculina y el de un imaginario subalterno que corresponde a una perspectiva femenina. Siendo la casa el entorno habitual, en este imaginario, se produce también el enfrentamiento entre la Mujer Dicha en vasta proliferación de signos producidos por una imaginación/discurso de carácter androcéntrico y la "Mujer Diciéndose a Sí Misma”.

La casa en imaginarios urbanos producidos desde una perspectiva femenina, es un signo que oscila en una pluralidad de significados gestados por una ideología determinada, por un concepto siempre cambiante acerca de la mujer. Carga conceptual que nos conduce a definir la casa como un ideologema en cuya elaboración va primando una posición ideológica con respecto a la experiencia de ser mujer y a los derechos que se exigen en un contexto político determinado. Es importante, además, señalar que las productoras de este imaginario acerca de la casa pertenecen a la clase media o a la alta burguesía, hecho que ciertamente omite perspectivas minoritarias a nivel social y étnico.

LOS CONTORNOS SUBVERSIVOS DE “EL ÁNGEL DEL HOGAR”

Durante el siglo XIX circulaba en Latinoamérica la imagen del "ángel del hogar”figura que complementaba a la Virgen María como modelo prescriptivo de las virtudes y deberes de la mujer-. Tanto para románticos (Rousseau) como para positivistas (Comte), la división de los sexos era una ley natural que ubicaba a los hombres en la esfera de la razón y el sentido práctico mientras la mujer era un ser eminentemente espiritual que protegía y cuidaba del hogar. "El ángel del hogar" resultó una figura clave en la formación de las naciones latinoamericanas, razón por la cual era frecuente en sermones eclesiásticos, revistas de corte positivista o de contenido dirigido a las mujeres, en ensayos sobre la nación y en textos literarios. En los folletines de la época, eran corrientes las ilustraciones de esta nueva versión de la Madona, ahora velando el sueño de un hijo en su cuna mientras cose o borda con la actitud beatífica de quien cumple la noble misión de resguardar el sagrado hogar.

Sin embargo, esta imagen del “ángel del hogar” adquiere otros rasgos en las novelas escritas por mujeres del siglo xIx. El texto fundacional de esta producción literaria es $S a b$ (1841) de Gertrudis Gómez de Avellaneda donde se dan índices de una escritura que se desvía del formato predominante en novelas escritas por hombres. En la superficie, Sab

\footnotetext{
(3) Revista Iberoamericana, Vol. LXXVIII, Núm. 241, Octubre-Diciembre 2012, 819-837 ISSN 0034-9631 (Impreso) 
es una novela romántica de carácter abolicionista, a pesar de las ambivalencias racistas que se detectan. Carlota, como típica heroína romántica, se desplaza entre la naturaleza y su casa, lugar de rezos y ensoñaciones amorosas. Es sólo al final de la novela cuando esta superficie textual da paso a otra historia en un estratégico palimpsesto. En la carta que escribe el esclavo Sab antes de morir, declara que la esclavitud de las mujeres es aún peor que la propia porque ellas están atadas por las cadenas indisolubles del matrimonio. Es sólo entonces cuando la figura angelical de Carlota se convierte en un personaje trágico. No es feliz en su matrimonio y de noche, sale de la casa como un espectro para visitar la tumba de Sab y llorar sus infortunios sabiendo que está condenada a una existencia sin salida.

La casa se elabora así como un espacio de doble pliegue: el de la metanarrativa patriarcal que la postula como la culminación del final feliz en historias de amor y este otro, desde una perspectiva feminista, que la concibe como una celda, como el entorno cerrado y esclavizante para la mujer que no posee ninguna agencia con respecto a su propia vida. Visión que responde a la influencia de George Sand en una ideología que critica duramente la institución del matrimonio e intenta desestabilizar los códigos del orden patriarcal.

En Dos mugeres (1842), la posición feminista de Gómez de Avellaneda se hace aún más explícita por la negación de los valores patriarcales, la ambigüedad y la afirmación de una voluntad propia (Picon Garfield 115-146). Dentro de este contexto ideológico, los personajes constituyen en sí un desvío de las estructuras convencionales, no sólo por el hecho de que el adulterio se considere un acto justificable, sino también porque Carlos se feminiza mientras Catalina resulta ser una apropiación feminista de la figura del héroe romántico. Lejos de poseer la pasividad y la virtud atribuidas a "el ángel del hogar”, Catalina tiene una viva inteligencia, una imaginación poética y la capacidad de vivir una gran pasión a través de la cual trasciende espiritualmente hacia el orden divino.

Sin embargo, sus impulsos naturales están condenados al fracaso por circunstancias históricas que han tronchado para la mujer toda posibilidad de realización: "Pero ¡la pobre muger, sin más que un destino en el mundo! ¿qué hará, qué será cuando no puede ser lo que únicamente le está permitido?” (Gómez de Avellaneda 94).

El desfase entre sus aspiraciones y aquellos límites impuestos por la sociedad patriarcal crean en la novela una diglosia que posee el espacio de la casa como correlato objetivo. La casa de Carlos y Luisa es el espacio del orden y la convención mientras que la casa de Catalina es el espacio ilícito en el cual no sólo transcurren los episodios del adulterio sino también las actividades intelectuales. De este modo, la casa aloja lo reprimido en la mujer de la época: su sexualidad y su inteligencia. Para comprender este binomio que ahora nos parece insólito, baste recordar que, a la par de las prescripciones sexuales, se estaban produciendo discursos en contra de la educación de la mujer argumentando que la energía gastada en lo intelectual mermaba la capacidad de la

\footnotetext{
Revista Iberoamericana, Vol. LXXVIII, Núm. 241, Octubre-Diciembre 2012, 819-837 ISSN 0034-9631 (Impreso) ISSN 2154-4794 (Electrónico)
} 
reproducción biológica la cual debía ser su única meta (Russet 116-123). El hecho de que Catalina, al final de la novela, se encierre en un cuarto de su casa y se suicide asfixiándose representa el impulso de autonomía de la protagonista quien decide su propia muerte y simultáneamente denuncia las limitaciones impuestas a la mujer. Desde una posición subalterna, Gómez de Avellaneda emite un discurso condenado a la derrota y el cuarto cerrado con sus vapores venenosos alude a esta modalidad hermética de la existencia.

De manera significativa, son también los espacios cerrados de la casa los símbolos de la hermeticidad en los textos de Soledad Acosta de Samper quien concibe a la mujer como un ser condenado al dolor. En su artículo titulado "El corazón de la mujer (Ensayos psicológicos)" (1869), la autora afirma: "Las mujeres no tienen derecho a desahogar sus penas a la faz del mundo. Deben aparentar siempre resignación, calma y dulces sonrisas; por eso ellas entierran sus penas en el fondo de su corazón, como en un cementerio, y a solas lloran sobre los sepulcros de sus ilusiones y esperanzas” (239). Visión que la hace definir a sus protagonistas como flores marchitas encerradas en la casa que se compara con un negro atáud. Por otra parte, la enfermedad romántica (tuberculosis, afección al corazón o melancolía que empalidece las mejillas satisfaciendo el modelo de belleza femenina que predominaba en la época para reforzar la debilidad culturalmente adscrita a la mujer), se elabora a nivel de la monstruosidad. Así, en "Dolores. Cuadros de la vida de una mujer" (1869), la lepra deforma la palidez de la tez incentivada por el uso de sombrillas y polvos de arroz para convertirse en "palidez amarillenta", en una "cutis áspera de color morado" (152) que obliga a la protagonista a recluirse en un cuarto cerrado mientras vive la agonía del horror hacia su propio cuerpo.

\section{LOS ESPACIOS MARGINALES DEL PLACER Y LA ESCRITURA}

Hacia 1920, los ecos de las sufragistas europeas y norteamericanas llegaron a Latinoamérica de la misma manera como las nuevas modas irrumpieron en las revistas de la época. Las faldas cortas y los collares largos simbolizaron, a un nivel concreto, el despojo del corset y las enaguas con armados, como si dichos alambres hubieran sido las cercas del cuerpo. El modelo de la belleza femenina, ahora de melena y cintura libre para hacer los pasos del charleston, adquiere también los visos deslumbrantes del cine -industria que con la inventiva de Max Factor y otros especialistas en vestuario crean la nueva imagen de la mujer como muñeca y explícito objeto sexual despojado de los eufemismos y ocultamientos del siglo XIX-. Las ideologías feministas, por otra parte, se proponen un nuevo horizonte: el derecho a voto que renueva la utopía de la igualdad de los sexos y que sólo se logrará en Latinoamérica hacia 1950.

Ifigenia. Diario de una señorita que escribió porque se fastidiaba (1924) de la escritora venezolana Teresa de la Parra se inscribe en este nuevo contexto. De manera significativa, "la casa virtuosa y severa" (328) definida como presidio y símbolo del

\footnotetext{
Revista Iberoamericana, Vol. LXXVIII, Núm. 241, Octubre-Diciembre 2012, 819-837 ISSN 0034-9631 (Impreso) ISSN 2154-4794 (Electrónico)
} 
Orden se abre en el resquicio del "cuarto propio"-lugar que aloja tanto la escritura como el placer narcisista-. Contratexto espacial de la novela que, como género eminentemente masculino y burgués, utilizaba la privacidad de la casa para reforzar el ocio de la mujer burguesa en su consumo de folletines y novelas reiterando, en la ficción, aspiraciones y modelos de conducta asignados por la sociedad a las mujeres (Watt, Armstrong). Si en el caso de las novelas de Richardson, por ejemplo, la heroína se encierra en su cuarto para escribir sus vicisitudes sentimentales, en Ifigenia, el cuarto privado, como espacio escritural y narcisista, es la morada de lo ex-céntrico, de aquello que resulta contestatario para el sistema convencional.

Es en ese cuarto dotado de un espejo en el cual se invierte la función de la ropa y el maquillaje dirigidos a una mirada masculina para transformarlos en fuente de placer para la mirada propia. La voluptuosidad de la seda, la caricia de la esponja de los polvos o el toque luminoso del Guerlain y el Rouge vif de Saint-Ange son parte de un ritual que constituye a María Eugenia fuera del ámbito de los paradigmas falogocéntricos. Esto no sólo por el valor subversivo del adorno como superficie efímera que descalifica las nociones de profundidad, verdad e identidad, según los planteamientos de Nietzsche y Baudrillard, sino, más que nada, por la jouissance de un placer femenino autónomo que excede el sistema del lenguaje y omite el predominio atribuido al falo como agente activo e imprescindible para la sexualidad femenina. Esta jouissance duplica su valor transgresivo en la escritura que deviene en una inscripción de lo prohibido. Así, opiniones y sentimientos silenciados, fantasías y experiencias libidinalmente gratificantes son los trazos de la identidad de un Yo que se constituye en sujeto en los bordes de experiencias y discurso adscrito a la mujer burguesa.

Sin embargo, la autonomía de este sujeto está condenada a la clausura. De manera simbólica, son los espacios de la casa los que se bifurcan en dos alternativas: el boudoir -sitio de susurros y confidencias- donde Mercedes da voz a su insatisfacción en el matrimonio, y el corral en el cual la negra Gregoria, desde una posición irreverente, aboga por la libertad de la mujer. La disyuntiva de María Eugenia, al final de la novela, es precisamente optar por lo institucional (casarse) o lo ilegítimo (seguir a Gabriel en calidad de amante). Con plena conciencia de que está claudicando al Orden convencional, la protagonista inmola ropa, maquillaje y escritura en una clausura que hace de ella “una página en blanco” (316).

Hacia la década de los treinta, se inicia en la novela de la mujer latinoamericana una tendencia que escinde la existencia de las protagonistas en un Adentro y un Afuera, en un oscilar sin resolución entre los códigos restrictivos representados por la casa y la experiencia erótica que tiene como entorno los elementos primordiales del agua y la tierra. Las emisoras de este nuevo discurso que se prolonga hasta la década de los cincuenta, omiten todo horizonte político explícito para poéticamente elaborar una imagen de la mujer como un ser cuya sexualidad tronchada implica una pérdida del lazo

\footnotetext{
Revista Iberoamericana, Vol. LXXVIII, Núm. 241, Octubre-Diciembre 2012, 819-837 ISSN 0034-9631 (Impreso) ISSN 2154-4794 (Electrónico)
} 
con todo lo natural. En un gesto de repudio soterrado hacia la familia y otros órdenes, las protagonistas se aíslan en el espacio propio de lo subjetivo y los acontecimientos de la novela corresponden a una aventura interior en la cual se desarrolla la búsqueda solitaria de Eros, en un estado de enajenación con respecto a la realidad exterior y el devenir histórico.

Es interesante observar que el espacio de la casa equivale también al espacio del tedio y del hastío, de un ocio burgués que subraya el vacío de la existencia. Por lo tanto, las protagonistas abandonan la casa para iniciar breves peregrinaciones "reales" o "imaginadas" por las calles de una ciudad desconocida, por el bosque o la playa en un estado de espera alucinada. Así, en El abrazo de la tierra (1933) de María Flora Yáñez, se dice:

Adivina los días monótonos, sin más objetivo que la labor doméstica a la vera del brasero. Imagina las conversaciones insulsas, siempre sobre los mismos temas, el hastío en común; la vida estancada en que las pasiones duermen arrulladas por el concierto imperturbable de los grillos y las ranas [...] siempre igual, hoy, mañana, y todos los días que siguen, y las semanas y los meses y los años, hasta que al fin vendrá la muerte, silenciosa como fue la vida, y todo concluirá. (126)

Dentro del contorno opresivo de la casa, la única alternativa posible parece ser la imaginación que se canaliza sólo en la fantasía erótica, en un Deseo específicamente sexual que gesta y motiva la aventura. Si, por una parte, dicho Deseo se eufemiza y sentimentaliza en una retórica del amor que lo define como la única posibilidad de realización para la existencia femenina, simultáneamente, en una diglosia producida por la censura patriarcal y la autocensura que no permiten la modelización explícita de la sexualidad, las experiencias eróticas se elaboran en un lenguaje poético y en la ambigüedad de lo real y lo ensoñado. En este sentido, la escena de La última niebla (1935) de María Luisa Bombal en la cual la protagonista se sumerge desnuda en el estanque resulta reveladora:

\begin{abstract}
No me sabía tan blanca y tan hermosa. El agua alarga mis formas, que toman proporciones irreales. Nunca me atreví antes a mirar mis senos; ahora los miro. Pequeños y redondos, parecen diminutas corolas suspendidas sobre el agua. Me voy enterrando hasta la rodilla en una espesa arena de terciopelo. Tibias corrientes me acarician y penetran. Como con brazos de seda, las plantas acuáticas me enlazan el torso con sus largas raíces. Me besa la nuca y sube hasta mi frente el aliento fresco del agua. (14-15)
\end{abstract}

Contradiciendo el paradigma falogocéntrico que plantea la penetración fálica como único objetivo y culminación de la sexualidad, en estas novelas, el golpe recio de las olas, las tibias corrientes de aguas quietas o la tierra de aromas profundos y mojados o

\footnotetext{
Revista Iberoamericana, Vol. LXXVIII, Núm. 241, Octubre-Diciembre 2012, 819-837 
de una calidez enervante emanan una sensualidad que produce experiencias orgásmicas. Así, en Las cenizas, se dice:

Su sensibilidad agoniza exasperada por la gama de olores. Se tiende sobre la tierra parda y permanece durante horas, quieta, como petrificada, sintiendo el beso de las raíces en la piel del cuello y de los brazos. El crepúsculo la cubre de sombra; corrientes de savia circulan bajo el suelo y la envuelven [...] Es frágil espiga, es magnolia abierta. (72)

La casa en estas novelas se modeliza como símbolo de una civilización creada y regida por los hombres, como ese lugar que excluye a la mujer del devenir histórico y a la vez, troncha su lazo natural con todo lo cósmico. En Jardín, novela de Dulce María Loynaz escrita entre 1928 y 1935 aunque sólo publicada en 1951, la casa con su mueblaje decrépito, sus puertas cerradas y sus pájaros embalsamados representa la clausura de la vida en contraposición al jardín que la rodea como sitio fronterizo entre la civilización y lo primigenio. Bárbara recorre ese jardín sabiendo que "sus bienes eran el sol y la lluvia, y no a la manera que los poseen los hombres, como una simple división de días y estaciones, sino como la fuerza viva, la alegría viva, la vida misma, que son para las criaturas vegetales” (68). Bárbara es el jardín, esa naturaleza controlada por senderos y canteros mientras se da, de manera latente, esa otra fuerza natural que germina sin la intervención del Homo Faber. Después de vivir en la ciudad, Bárbara regresa al jardín de su casa, ahora convertido en selva y es absorbida por él en un descenso a la exudación vegetal, al espacio de resinas, fango y constante germinación.

Esta visión de "lo femenino" intrínsecamente ligado a la naturaleza primordial se observa también en La amortajada (1938) de María Luisa Bombal donde la primera experiencia sexual de la protagonista ocurre fuera de la institución del matrimonio y las convenciones patriarcales. Esta experiencia marginal al orden tiene lugar en un espacio aún no penetrado por la civilización ("rosales erizados, árboles caídos cuyos troncos mojados corroía el musgo; hollaba lechos de pálidas violetas inodoras, y hongos esponjosos que exhalaban, al partirse, una venenosa fragancia, [103]). Según la noción prevalente en estos textos, éste es el verdadero entorno de la mujer cuya "esencia" está enlazada a la naturaleza primordial. De allí que el matrimonio y la casa como espacio de deberes y represiones conviertan a Ana María en un ser degradado y mezquino que sólo logra redimirse después de la muerte en una reintegración al espacio cósmico ("nacidas de su cuerpo, sentía una infinidad de raíces hundirse y esparcirse en la tierra como una pujante telaraña por la que subía temblando, hasta ella, la constante palpitación del universo", [162]).

Desde esta perspectiva, se construye también un contratexto de la masculinidad como construcción cultural que la define en el ámbito de la agresión y la competencia civilizadora, para presentar al amante real o imaginado como una extensión de la naturaleza: él es un cuerpo del cual emanan los olores ásperos de la tierra (El mundo

Revista Iberoamericana, Vol. LXXVIII, Núm. 241, Octubre-Diciembre 2012, 819-837 
dormido de Yenia, 1946, de María Carolina Geel), la fragancia sensual del trigo maduro y las frutas recién cogidas (Las cenizas, La última niebla), el mar con su oleaje vital (Jardín) o el perfume enervante de un oscuro clavel silvestre (La amortajada).

De esta manera, el flujo y reflujo de las aguas junto con la tierra y la vegetación devienen en una corriente subversiva de la líbido que pone en entredicho importantes ejes de la axiología falogocéntrica. Dentro de esta visión contestataria, es interesante observar que la única vez que la casa aparece como albergue de la sexualidad femenina (La última niebla), ésta está despojada de todo objeto perteneciente al orden de las familias. Es el retorno a esa casa, ahora investida de los signos de identidad de la familia convencional, el suceso que marca, en la trayectoria de la protagonista, la pérdida irrevocable de aquel amante real o ensoñado que sublimó, a través de la escritura y la fantasía erótica/sentimental, el vacío de su existencia de mujer burguesa.

Paseo una mirada a mi alrededor. ¿Y esta casa, qué tiene que ver con la de mis sueños? Hay muebles de mal gusto, telas chillonas, y en un rincón cuelga, de una percha, una jaula con dos canarios. En las paredes, retratos de gente convencional. Ni un solo retrato en cuya imagen pueda identificar a mi desconocido. (40)

La derrota de Eros en La última niebla es un leit-motiv que se reitera en las otras novelas aquí comentadas. Las aventuras se clausuran definitivamente y las protagonistas, no obstante han adquirido conciencia de las inadecuaciones del orden patriarcal, deben claudicar a la convencional vida de la casa, definida como "muerte en vida" (La última niebla, Extraño estío, 1948, de María Carolina Geel) y como "muros coloniales” (El abrazo de la tierra). La única otra alternativa es reintegrarse a la naturaleza primigenia después de muerta, en una fusión que anula toda agencia histórica.

No obstante se da una conciencia de la subordinación de la mujer, este hecho histórico se diluye en un esencialismo que lo reemplaza por "una naturaleza intrínseca" y "un ciego destino". A esta contradicción, se añade el hecho de que el amor y lo sentimental se reinscriben en un discurso de la sexualidad altamente subversivo para la época. Y es la noción que liga la "esencia" de la mujer a lo primigenio natural la que permite elaborar lo libidinal en un entorno poético que resguarda de la censura. De esta manera, la evasión de todo devenir histórico a partir de nociones esencialistas adquiere también los índices de una escritura transgresiva.

\section{LA REAPROPIACIÓN DE LA CASA COMO SITIO DE LA HISTORIA PROPIA}

Los diversos movimientos feministas que se inician hacia fines de la década de los años sesenta, borran, de manera beligerante, los trazos de todo esencialismo para regenerar la problemática de la mujer en una especificidad histórica y cultural. El cuerpo de la mujer ya no es simplemente una topografía sexual silenciada y eufemizada, sino

\footnotetext{
Revista Iberoamericana, Vol. LXXVIII, Núm. 241, Octubre-Diciembre 2012, 819-837 
también un cuerpo político que denuncia la desaparición de un hijo durante la dictadura y un recurso teórico para desestabilizar los paradigmas impuestos por el sistema falogocéntrico. La categoría "mujer”, generalmente postulada como una abstracción generalizante, se contextualiza en términos de raza y clase social proliferando en una múltiple polifonía de la subalternidad que empieza a construir su propia historia, a través del rescate de cartas y memorias escritas por mujeres, ya a partir de la época colonial y de la transcripción de testimonios entregados por mujeres indígenas, tales como Domitila Chungara y Rigoberta Menchú.

Es más, surge la noción de género, como una construcción cultural sujeta a los devenires de un poder patriarcal que, lejos de ser estático, construye, en diversos contextos históricos, metanarrativas específicas acerca del signo "mujer" (Guerra, La mujer fragmentada). Desde esta nueva perspectiva, se empiezan a deconstruir las ficciones de "lo femenino" y "lo masculino" legitimando la homosexualidad que, hasta ahora, se definía dentro del campo semántico de la desviación, la enfermedad o la perversidad. Así, estas categorías construidas como verdaderos estamentos se pueblan de intersticios y fisuras, dando a luz la noción de género como puesta en escena de un guión performativo escrito por los grupos hegemónicos del patriarcado (Butler).

Desde una perspectiva iconoclasta que niega la supremacía del Falo, como emblema del Orden Simbólico, la casa es invadida por la blasfemia y la herejía. Narcisa la Sin Nombre en Hagiografía de Narcisa la Bella (1985) de Mireya Robles es el contratexto subversivo de lo canónico y canonizante, aquí planteado como estructura familiar, hagiografías y sicoanálisis. Ella es una santa a quien no se le reconocen sus milagros, especialmente porque el milagro y los sacramentos son patrimonio de los hombres. Y, a diferencia de los martirios espantosos que han permitido a las mujeres lograr la canonización papal, Narcisa se crea a sí misma en la autocontemplación y la creación de su propia perfección. Contradiciendo el concepto de Lacan, la imagen en el espejo no produce la percepción de la fragmentariedad sino la apropiación de una autonomía. Pero, ¿hasta qué punto la mujer aislada de su entorno social se puede inventar a sí misma? ¿Qué hay más allá de la parodia y la deformación grotesca de la estirpe familiar? El desenlace de la novela nos lleva a un callejón sin salida. La auto-inmolación de Narcisa es seguida por el acto canibalístico de los miembros de la familia que se sirven tajadas de su cuerpo; al darse cuenta de que no podrán comérsela entera, el padre ordena que las sobras vayan "a los funerales que hay que celebrar para el pueblo" (155). Retorno al ritual convencional de la familia, frase que, a propósito, no va seguida de un punto final, como si el orden de las familias, se eternizara en su poder y lo paródico fuera solamente un intersticio fugaz.

En una línea similar, aunque utilizando una variedad más amplia de elementos posmodernos, Casa en llamas (1989) de Milagros Mata Gil presenta la desacralización absoluta de la familia y todo principio de autoridad, incluida la autoridad de los narradores

\footnotetext{
Revista Iberoamericana, Vol. LXXVIII, Núm. 241, Octubre-Diciembre 2012, 819-837 ISSN 0034-9631 (Impreso) IISSN 2154-4794 (Electrónico)
} 
en la novela. Desde los bordes de todo sistema, la casa se preña de significados múltiples y dispares: es el vientre materno y el vientre de lo visceral abyecto, es cripta de piedra y lodo, eje de la autoridad patriarcal y azogue de los espejos difusos de la memoria. Allí aloja también el desecho, la vejez decrépita, los espectros fantasmales y el pastiche grotesco de los títeres. El títere que narra la historia de la casa, sinónimo también de la Nación venezolana, se define a sí mismo como “máscara”, “cascarón vacío” y “concha de caracol botada en la playa” (185). En la imitación ridiculizada que hace de los forjadores de la historia oficial del país, sus discursos se polucionan de elementos de la cultura de masas (canciones, frases de melodrama, chichés de los anuncios comerciales).

En la ecuación Casa-Padre-Nación, la blasfemia desacralizadora socava a partir de la risa, la mentira, la hipérbole y el trastocar de las categorías genéricas en este otro Teatro del Mundo que se define como "fauna extravagante y estrafalaria" (66). La teatralización carnavalizadora de los cimientos de la sociedad patriarcal con sus roles y rituales específicos es, en La casa en llamas, un acto de exorcismo y purgación simbolizada, al final, por el fuego que destruye y purifica la casa dando paso al agua del río, en un flujo vertiginoso que elimina todos los estancos.

Un aspecto clave del feminismo latinoamericano actual ha sido el intento de legitimar aquellos saberes que han permanecido a nivel de una subcultura creada por las mujeres en el espacio de la casa. Los conceptos silenciados acerca de la menstruación y la maternidad, la influencia de los quehaceres domésticos en una visión particular del mundo y la difusión no-oficial de saberes en el entorno de la casa empiezan a configurar todo un acervo cultural de la mujer que, hasta ahora, había sido un espacio en blanco.

En la tradición cultural de la mujer mexicana, la reflexión estratégicamente ingenua de Sor Juana Inés de la Cruz quien exclama en su "Respuesta a Sor Filotea" que si Aristóteles hubiera cocinado, habría escrito mucho más, marca el umbral de una serie de textos en los cuales la cocina se inscribe como espacio axial. La defensa de "la filosofía de la cocina" en el ensayo de Sor Juana tiene fundamentos concretos, como demuestra Jean-Francois Lyotard al señalar que en el vocablo sophia , la raíz soph -es idéntica a la raíz del latín sap-, sapere, y del francés savoir y savourer. Sabor y saber son, en sus orígenes, una conjunción que se fragmenta al relegar lo doméstico a la esfera de lo no cultural.

Como agua para chocolate (1989) de Laura Esquivel se inscribe tanto en una intertextualidad literaria (Rosario Castellanos, Amparo Dávila) como en el acervo subcultural de las recetas, escritas y mantenidas en los conventos fundados durante la Colonia o circulando en las familias a través de varias generaciones (Muriel). En la cocina, los saberes de Tita la dotan de un tipo de poder dirigido hacia el paladar y el estómago de los comensales; sus guisos transforman los humores, enferman o seducen en una economía del alimento a través del cual el Homo Sapiens retorna al estado primigenio de un cuerpo que se nutre. Su nacimiento en la mesa de la cocina marca el ingreso a

\footnotetext{
(3) Revista Iberoamericana, Vol. LXXVIII, Núm. 241, Octubre-Diciembre 2012, 819-837 ISSN 0034-9631 (Impreso) 
una marginalidad que, desde aquello fuera de un centro, lo interviene y lo interrumpe. En la cocina, se conjura y se amamanta, se amasan, con nuevos ingredientes, relaciones humanas con mujeres en una doble subordinación (la campesina Chencha y la india Nacha) y se establece otra noción de dominio ("lo que colindaba con la puerta trasera de la cocina y que daba al patio, a la huerta, a la hortaliza, sí le pertenecía por completo, lo dominaba” [6]). El dominio aquí nada tiene que ver con el poder patriarcal y sus territorializaciones, se trata del dominio de la naturaleza en su dimensión nutritiva, del alimento que Tita, desde el ámbito de la creatividad y el placer transforma, como una verdadera alquimista (figura de la mujer también elaborada en la pintura mexicana por Remedios Varo y Leonora Carrington).

La casa se divide en cuartos jerarquizados, verdaderos signos del poder en cuanto a las represiones que produce en la institución de la familia. La sala corresponde a aquello que puede verse, las alcobas a lo que, a pesar de la privacidad, puede inspeccionarse mientras el cuarto oscuro en el cual se baña desnuda Mamá Elena (encarnación a nivel público de la autoridad patriarcal), es el espacio vedado y oculto donde se mantiene el secreto de sus transgresiones sexuales. De manera significativa, ese cuarto posteriormente se transforma en la habitación donde se acumulan objetos desechados ("cuarto de los triques” [158]) y es allí donde tienen lugar los amores clandestinos de Tita y Pedro.

La dicotomía entre el centro autoritario y los ex-centrismos de Tita se recicla en un presente en el cual la sobrina-nieta lee el texto de su antepasada y lo da a conocer. Pero, a diferencia de la receta tradicional (hoja suelta o libro artesanal y doméstico que circula entre las mujeres y se sigue textualmente o con mínimas modificaciones), la historia de este texto se reelabora desde una perspectiva posmoderna a través de la cual se parodian y exageran los discursos del folletín y el melodrama, el Manual de Carreño, el llamado "realismo mágico" e incluso, el formato convencional de la novela (Glenn). El subtítulo "Novela de entregas mensuales, con recetas, amores y remedios caseros" apunta tanto a lo anacrónico (folletín del siglo xix) como a lo heterogéneo donde el amor, la receta y el remedio casero resultan ser una conjunción que transgrede las construcciones sentimentales del amor. En Como agua para chocolate, más allá de las implicaciones filosóficas del sabor y el saber, se erige la historia de una mujer a quien le estuvo vedado no sólo decidir sobre su propia vida sino también participar en el devenir histórico. Significativamente, Tita al hacer el amor a Pedro, se construye un orgasmo propio en una posición de agente del placer y la quemazón de la casa que se carboniza constituye en sí la alegoría de un pasado sin posible retorno.

Si en la novela de Esquivel, la Historia es el devenir tangencial que fermenta de manera oculta, en El exilio del tiempo (1990) de Ana Teresa Torres, deviene en una sucesión de eventos que se corrigen a partir de una perspectiva feminista. Contradiciendo la oposición entre "lo público" y "lo privado", la casa es parte de la Historia. Desde los tiempos coloniales, ve pasar por su puerta los signos de un devenir marcado por

\footnotetext{
Revista Iberoamericana, Vol. LXXVIII, Núm. 241, Octubre-Diciembre 2012, 819-837 ISSN 0034-9631 (Impreso) ISSN 2154-4794 (Electrónico)
} 
la concreticidad de los edificios que se construyen a su alrededor y, en su interior, sus habitantes asumen vestiduras reales e ideológicas en un spectrum que va de la colonia a la república, de la dictadura de Pérez Jiménez a la democracia y el boom del petróleo. Se da, así, una re-visión de la noción de Historia por una narradora que, en su posición de cronista y amanuense, recoge las huellas históricas en documentos de la familia (objetos, fotos, cartas), en los decires dentro de la casa, en todo aquello que oficialmente se considera "minucia o chismes de mujeres”. Es precisamente el carácter heterogéneo de esta documentación el que, yendo contra el discurso monológico de la Historia oficial, se erige en la novela como una polifonía de lo subalterno.

Por otra parte, la narradora se destaca como una mujer que se constituye en sujeto a través de una genealogía de mujeres que dan testimonio de la fragmentación étnica impuesta por la Nación, de sus discriminaciones e injusticias. La casa es, así, el sitio de la memoria que nutre e identifica, pero, en el entrecruce de voces y objetos domésticos, la historia no logra completarse, jamás llega a ser esa Totalidad objetiva a la que aspira la Historia hegemónica. Por el contrario, la narradora, al final de la novela, se enfrenta con “pedazos desarticulados” (263) que sólo se pueden rearticular a través de una ficción en la cual la escritura se centra en la casa para descentrar y socavar aquellas otras ficciones creadas por la historia oficial. De este modo, se historiza y problematiza aquello que, en la tradición literaria masculina, se ha mitificado como "lo lárico" -fogón ancestral y sagrado del hogar que es sitio de las raíces identitarias, de lo permanente como vera que resguarda del flujo arrasador del tiempo y el devenir histórico-.

Internándose aún más en esta problematización feminista de la casa y de la Historia, Mercedes Valdivieso escribe Maldita yo entre las mujeres (1991) basada en la figura colonial de la Quintrala quien, según la leyenda, envenenó a su padre y tiró por la ventana el crucifijo del Cristo de Mayo. La casa de la Quintrala en la novela es un dominio propio, no aquel lugar regido y adjudicado por la estructura patriarcal, sino el espacio donde se gesta la autonomía rebelde, aquella axiología que rechaza la Ley del Padre y transforma "lo político" en enlazamiento maternal.

Las implicaciones de esta casa propia se extienden a la construcción de la nación chilena puesto que el architexto que recoge la historia de la Quintrala es uno de los fundadores de aquel proyecto en el siglo xIx. Los Lisperguer y la Quintrala (1877) de Benjamín Vicuña Mackenna se escribe desde la perspectiva positivista de la hegemonía blanca y urbana con el propósito no sólo de mostrar los excesos perversos de la Colonia sino también para reafirmar los valores de esa ideología. La Quintrala (de "quintral”, flor venenosa que crece en el sur de Chile) es la "hembra indómita y salvaje" (Vicuña Mackenna 74), tierra sin cultivar aliada a la brujería y el mal debido a "sus afinidades íntimas y cercanas con la raza indígena” (74). El texto de Vicuña Mackenna tiene como objetivo el blanqueamiento de la nación y la consecuente eliminación del elemento indígena estableciendo prescripciones para una identidad chilena que debe forjarse

\footnotetext{
Revista Iberoamericana, Vol. LXXVIII, Núm. 241, Octubre-Diciembre 2012, 819-837 ISSN 0034-9631 (Impreso) 
a partir de la razón, la sobriedad y la mesura. La sexualidad y los crímenes de la Quintrala inscriben el exceso como un No-Deber-Ser a través de la hipérbole del Mal y la desviación mórbida.

Desde una posición disidente, Valdivieso estructura Maldita yo entre las mujeres a partir de un Yo y un "Dicen que", o sea, en la dicotomía de la casa propia y el Afuera (sistema e instituciones patriarcales). Dentro de su casa, la identidad propia se entrelaza a las figuras genealógicas de la madre, de las abuelas y las bisabuelas: "Esa soy, padre / hija de Llanka Curiqueo / que es hija de Elvira de Talagante / que es hija de Agueda Flores / que es hija de Catalina / que es mi madre / que soy yo" (141-142). Estirpe de mujeres anclada en el útero y fuera de las sistematizaciones creadas por el poder falogocéntrico. Esta casta, en su marginalidad subversiva, soberbiamente se erige como una amenaza para el proyecto de Nación al estar unida a la raza indígena en una mezcla de lo oficialmente calificado como "sangres impuras". Catalina dice:

El bastardaje que nos marca a las mujeres de mi casta, empezó en mi bisabuela doña Elvira, cacica de Talagante. Y doña Elvira se negó al casorio con Bartolomé Blumen para conservar sus tierras y seguir su propia vida. $\mathrm{Al}$ año de amancebada con el alemán y cuando su vientre enseñaba las consecuencias, éste quiso dignarle su nombre, pero manceba y libre sería ella misma en este mandar de varones, dijo sin afanarse. (33)

El mestizaje implica una historia de sangre y guerra, de rebeldías indígenas que nunca lograron ser domadas por el conquistador español, y la mujer que nace de esa casta se considera “mujer cruzada por dos destinos, lo que era ser mujer dos veces” (37). Contradiciendo los conceptos del coloniaje español y la nación chilena que asociaban lo indígena con lo bárbaro y hereje, en el territorio de este linaje bastardo de mujeres, la sabiduría proviene del entorno mapuche. En este sentido, la figura de Tatamai -nana, madre/ maestra, cómplice y amiga de Catalina- es altamente significativa:

De meica para los males, la Tatamai conoce los cuatro rincones del viento y los tres de la Trinidad, oye crecer las yerbas y andar los animalitos. Tenía que enseñar a recibir la vida pero también a terminarla, secreto que no deja huellas. Cruzando el río, la Tatamai empujó a su querido y, de ganarse el cielo por el sufrimiento, pasó a ser doña de la tierra. Si el diablo le aconsejó la libertad, a él había que arrimarse. (39)

Desde perspectiva feminista, Valdivieso enjuicia el Mal atribuido a la Quintrala dentro de un contexto patriarcal que mistificó la imagen de la virgen María como recurso para mutilar toda agencia en la mujer creando, al mismo tiempo, sus deformaciones pecaminosas en la figura de Eva y la bruja. En Maldita yo entre las mujeres, la oración a la virgen María se contradice y el vocablo "maldita” que reemplaza a "bendita” deviene en sinónimo de rebeldía, auto-determinación, libertad y sabiduría.

Revista Iberoamericana, Vol. LXXVIII, Núm. 241, Octubre-Diciembre 2012, 819-837 ISSN 0034-9631 (Impreso) 
A la casa de Catalina llegan las voces y premoniciones de sus antecesoras, las enseñanzas que arrojan luz en múltiples partos de lo subversivo femenino. En su casa, por derecho propio, la amamantan los conjuros y rebeldías que amenazan la estabilidad de esa otra casa ajena -la Patria, es decir, el territorio del Padre, según la etimología de esta palabra que durante la Edad Media correspondía a la iglesia como el lugar de Dios. Compartiendo los conceptos de Luce Irigaray, dentro de la casa se establece un cuerpo a cuerpo entre mujeres que ofrecen otra alternativa para la comunidad imaginada de la nación y es allí donde aparece la dios-madre en su vestimenta mapuche, como símbolo contratextual de la cultura blanca y androcéntrica.

En la novela de la mujer latinoamericana, la casa resulta ser un signo en constantes resemantizaciones filtradas por una ideología específica inserta, a la vez, en los diversos contextos políticos de los planteamientos feministas. Contradiciendo una perspectiva masculina que la asocia con el útero, la permanencia y una continuidad que sirve de soporte para los avatares y desafíos de un Afuera, en estos imaginarios, la casa se despoja de toda estaticidad. Ubicada en los vaivenes de la diseminación, la casa emite una proliferación de significados diversos y se convierte en una matriz contestataria que hace de las oscilaciones, el signo plural de un adentro silenciado y subalterno.

\section{BiBLIOGRAFÍA}

Acosta de Samper, Soledad. Novelas y cuadros de la vida suramericana. Gante: Imprenta de Eugene Vanderhaegen, 1869.

Armstrong, Nancy. Desire and Domestic Fiction: A Political History of the Novel. Oxford: Oxford UP, 1987.

Bachelard, Gastón. La poética del espacio. México, D.F.: Fondo de Cultura Económica, 1975.

Baudrillard, Jean. Seduction. Nueva York: St. Martin's Press, 1990.

Bhabha, Homi K. "The World and the Home”. Dangerous Liaisons. A. McClintock, A. Mufty y E. Shohat, eds. Minneapolis: U of Minnesota P, 1997. 445-455.

Bombal, María Luisa. La última niebla. La amortajada. Barcelona: Seix-Barral, 1987.

Butler, Judith. Gender Trouble: Feminism and the Subversion of Identity. Nueva York: Routledge, 1990.

Esquivel, Laura. Como agua para chocolate. Nueva York: Anchor Books, 1989.

Giannini, Humberto. La "reflexión” cotidiana: Hacia una arqueología de la experiencia. Santiago: Editorial Universitaria, 1987.

Glenn, Kathleen M. "Posmodern Parody and Culinary Narrative Art in Laura Esquivel’s Como agua para chocolate”. Chasqui XXXI/2 (1994): 39-47.

Gómez de Avellaneda. Gertrudis. Dos mugeres. Obras de la Avellaneda. La Habana: Imprenta de Aurelio Miranda, 1914.

\footnotetext{
Revista Iberoamericana, Vol. LXXVIII, Núm. 241, Octubre-Diciembre 2012, 819-837 ISSN 0034-9631 (Impreso) ISSN 2154-4794 (Electrónico)
} 
Guerra, Lucía. La mujer fragmentada: Historias de un signo. Santiago: Cuarto Propio, 1995.

León, Luis de. La perfecta casada. Barcelona: Montaner y Simón, 1898.

Loynaz, Dulce María. Jardín. Barcelona: Seix-Barral, 1993.

Lyotard, Jean-Francois. “¿Por qué desear?”. ¿Por qué filosofar? Cuatro Conferencias. Barcelona: Paidós, 1989. 79-99.

Mata Gil, Milagros. La casa en llamas. Caracas: Fundarte, 1989.

Muriel, Josefina. Cultura femenina novohispánica. México: Universidad Autónoma de México, 1982.

Nietzsche, Friedrich. The Gay Science. Nueva York: Vintage Books, 1974.

Parra, Teresa de la. Ifigenia; diario de una señorita que escribió porque se fastidiaba. Caracas: Alfadi S.A., 1981.

Picón Garfield, Evelyn. Poder y sexualidad: El discurso de Gertrudis Gómez de Avellaneda. Atlanta: Rodopi, 1993.

Rendell, Jane. "Introduction: 'Gender-Space””. Gender Space Architecture. An Interdisciplinary Introduction. J. Rendell, B. Penner e I. Borden, eds. Nueva York: Routledge, 2000. 101-111.

Robles, Mireya. Hagiografía de Narcisa Labella. Hanover: Ediciones del Norte, 1985.

Russet, Cynthia Eagle. Sexual Science: The Victorian Construction of Womanhood. Cambridge: Harvard UP, 1989.

Torres, Ana Teresa. El exilio del tiempo. Caracas: Monte Ávila, 1990.

Valdivieso, Mercedes. Maldita yo entre las mujeres. Santiago, Chile: Editorial Planeta, 1991.

Vicuña Mackenna, Benjamín. Los Lisperguer y la Quintrala. Santiago: Zig-Zag, 1944.

Yáñez, María Flora. El abrazo de la tierra. Santiago, Chile: Imprenta Universitaria, 1933. Espejo sin imagen. Santiago, Chile: Editorial Nascimento, 1936.

Las cenizas. Santiago, Chile: Casa Nacional del Niño, 1942.

Revista Iberoamericana, Vol. LXXVIII, Núm. 241, Octubre-Diciembre 2012, 819-837 
